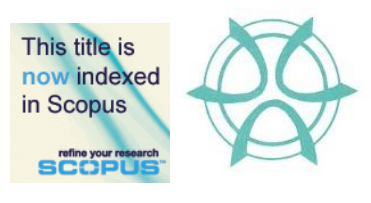

PLANNING MALAYSIA:

Journal of the Malaysian Institute of Planners

VOLUME 16 ISSUE 1 (2018), Page 211 - 221

\title{
KEY ISSUES IN THE MANAGEMENT OF THE HUMANITARIAN AID DISTRIBUTION PROCESS DURING AND POST-DISASTER IN MALAYSIA
}

\author{
Suzila Mohd ${ }^{1}$, Mohamad Syazli Fathi ${ }^{2}$, Aizul Nahar Harun ${ }^{3}$, \& Noraini Omar \\ Chong ${ }^{4}$ \\ ${ }^{1,3}$ Malaysia Japan International Institute of Technology \\ ${ }^{2,4}$ UTM Razak School of Engineering and Advanced Technology \\ UNIVERSITI TEKNOLOGI MALAYSIA, KUALA LUMPUR MALAYSIA
}

\begin{abstract}
The humanitarian aid distribution process is a broad activity for helping disaster victims at the right time, with the right needs and at the right place during a disaster. However, there are always issues that could interfere with the humanitarian aid distribution process such as cases of food redundancy, uneven distribution of food supply to disaster victims, food insecurity issues, and volunteers' redundancy during and post disasters. These issues prove that there are weaknesses in managing the humanitarian aid distribution process within disaster management teams. Generally, these issues should be taken care of when the disaster management team was formed either from government agencies or non-governmental organizations (NGOs). Both work as the supporting team in giving aids and helping the disaster victims. Therefore, this research reviews the key issues in the humanitarian aid distribution process in Malaysian disaster management. Key findings show that there is no standard operating procedure (SOP) to explain the roles and responsibilities of NGOs that can be used by Government agencies to coordinate NGO contributions to a supporting team. There are five (5) categories of issues that can have a negative impact on the humanitarian aid distribution process and the disaster victims. The issues are information, communication, collaboration, cooperation, and coordination. All disaster management teams should emphasize these issues as they affect effectiveness in dealing with the humanitarian aid distribution process.
\end{abstract}

Keyword: disaster management, humanitarian aid distribution, NGOs, humanitarian aid planning, humanitarian aid process 
Suzila Mohd, Mohamad Syazli Fathi, Aizul Nahar Harun, \& Noraini Omar Chong

Key Issues in The Management of the Humanitarian Aid Distribution Process During and Post-Disaster in Malaysia

\section{INTRODUCTION}

The beginning of the humanitarian aid community concept has developed since the second world war (Oloruntoba \& Gray, 2006; Thérien \& Llyod, 2000). At first, it only included multilateral agencies such as the United Nations High Commission for Refugees (UNHCR) and the World Food Programme (WFP), which are supported entirely by voluntary contributions from both government agencies and non-governmental organizations (NGOs) (Oloruntoba \& Gray, 2006). Since then, the role of humanitarian aid has spread out as a short-term relief goal in response to both man-made and natural disasters (Thérien \& Lloyd, 2000).

On top of that, the role of humanitarian aid in disaster management, especially during disaster occurrence, is to lighten up the burden of disaster victims. According to Mastouri, Rekik and Fath (2017), humanitarian aid may consist of tangible products (food, medicine, blankets, and water) or services (infrastructure maintenance and restoration of power lines). Both products and services will be distributed by disaster management teams (either government agencies, NGOs or both) to the disaster area or, more specifically, to the evacuation centres. This is in line with the role of humanitarian aid as a medium to accommodate and protect the disaster victims during and post-disaster.

In Malaysia, the National Disaster Management Agency (NADMA) was established on October 2015. It is a special agency fully dedicated to Disaster Risk Management (DRM) (Omar Chong \& Kamarudin, 2017). The roles and responsibilities of NADMA toward DRM are based on Directive No.20. Referring to the Directive No.20, Malaysia has established a Disaster Management and Relief Committee at federal, state and district levels in order to handle disasters effectively (Baharin, Shibghatullah, \& Othman, 2009; National Security Council, 1997). All levels are responsible for policy, tactical and operational coordination (Baharin et al., 2009). Moreover, during a disaster, Pos Kawalan Tempat Kejadian (PKTK) will be established in order to manage humanitarian aid at the disaster area, which consists of seven service themes. Details on the service themes will be discussed in following subsection.

The content of this research is based on a systematic literature review of the humanitarian aid distribution process in order to explore disaster management teams, the issues that occur in managing humanitarian aid and the main factors that should be emphasized in managing humanitarian aid that are within the scope of Malaysia. All information was gained from Government reports, conferences and journal papers that have been published from year 2000 to year 2017. The next subsection of this research discusses the roles and responsibilities of the Malaysian disaster management team as well as issues in managing humanitarian aid and its effects on disaster victims. 
PLANNING MALAYSIA

Journal of the Malaysia Institute of Planners (2018)

\section{ROLES \& RESPONSIBILITIES OF MALAYSIAN DISASTER MANAGEMENT TEAMS}

Disaster management teams, according to Asproth \& AmcoffNystrom (2010), may be from Government agencies, NGOs and spontaneous helpers or volunteers, which comprise individual citizens or a temporary group of citizens. Each of them will vary widely in agility, competence, resources and endurance (Asprot \& AmcoffNystrom, 2010). In Malaysia, on scene command post (PKTK) is established during disaster occurrences to ensure that disaster management is implemented in a holistic, coordinated and effective way (National Security Council, 1997). There are different types of agencies involved in PKTK, which are based on seven service themes: search and rescue, welfare, health and medical services, media, support, security control, and warning and alert (National Security Council, 1997; Omar Chong \& Kamarudin, 2017). Those service themes are specifically for the scope of Government agency services during managing a disaster and humanitarian aid (National Security Council, 1997). The Government agencies in each service theme are supported by the private sector as well as NGOs. Figure 1 lists the Government agencies involved in the seven service themes.

Additionally, the role of NGOs during a disaster is also important to reduce the burden on Government agencies in managing the humanitarian aid distribution process. NGOs are also known as implementing partners for Government agencies in order to accommodate and protect the disaster victims (Abiew, 2012). Furthermore, the need for cooperation from NGOs as supporting teams is stated in Directive No. 20 (National Security Council, 1997). However, the roles and responsibilities of NGOs in supporting Government agencies in providing humanitarian aid is not clearly defined under current legislation (i.e. Directive No.20). The roles and responsibilities of NGOs are loosely defined under each service theme, which allowed the NGOs to make their own decisions in providing humanitarian aid in any disaster with limited information gained from social media. In addition, based on an interview session with a NADMA Official (2017), there is no particular mechanism or tools to coordinate all NGOs and their various strengths and capacities. Thus, there was evidence of several cases of food redundancy, uneven distribution of food supply to disaster victims, food insecurity issues, and volunteers' redundancy during and post the 2014 Mega Flood disaster in Malaysia (Husain, Abdul Rashid, Zainol, Syed Mohamed, \& Ayub, 2014; Mat Taib et al., 2014; Yazid, Hussin, Wan Daud, Abdullah, \& Salleh, 2014). The following subsection of this article will clarify the issues on the humanitarian aid distribution process and their effects on disaster management. 
Suzila Mohd, Mohamad Syazli Fathi, Aizul Nahar Harun, \& Noraini Omar Chong

Key Issues in The Management of the Humanitarian Aid Distribution Process During and Post-Disaster in Malaysia

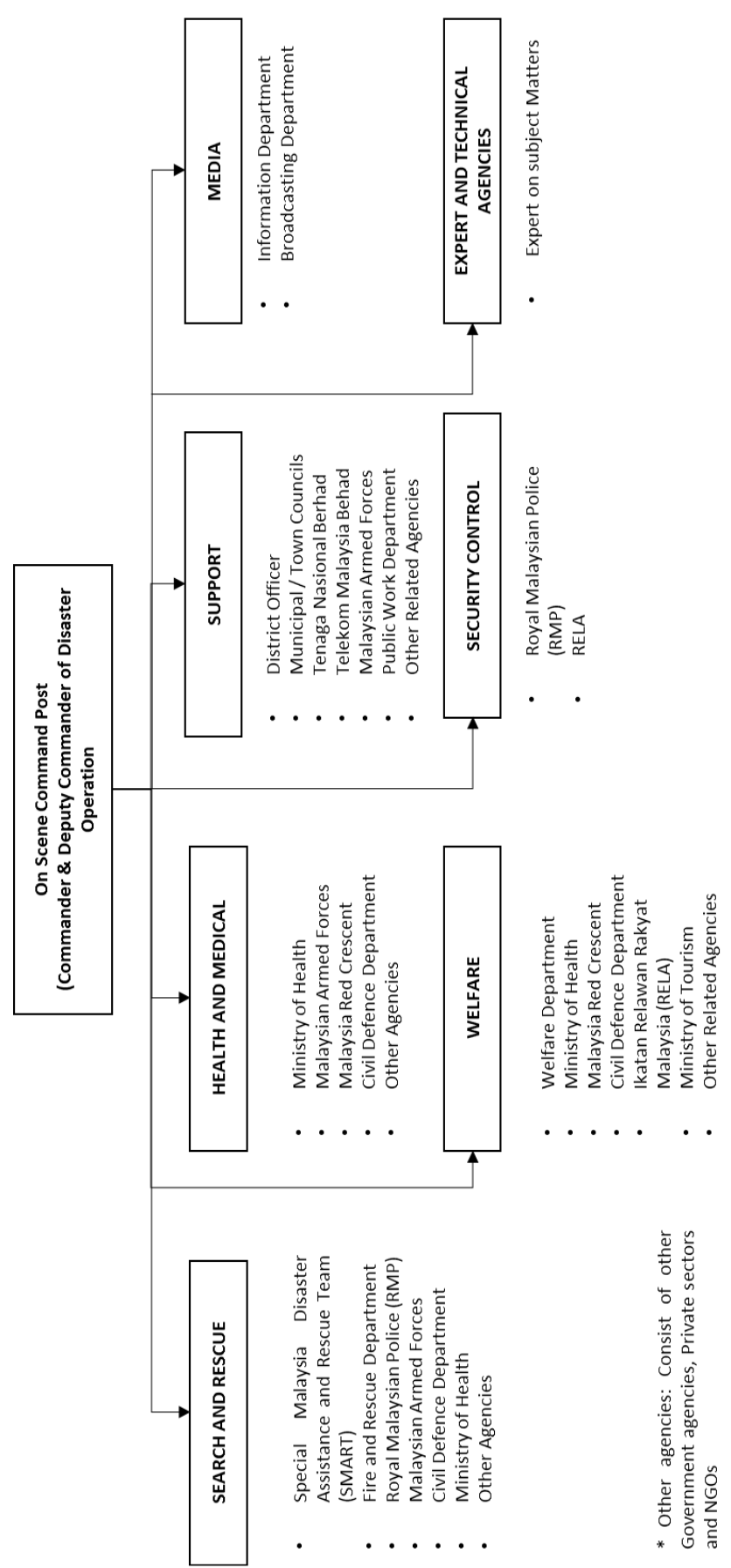

Figure 1: Agencies involved in PKTK during a disaster

Source: (National Security Council, 1997; Tan, Raswahan, Koh, Lim, \& Ismail, 2013) 


\section{ISSUES WITH THE HUMANITARIAN AID DISTRIBUTION PROCESS AND THEIR EFFECTS ON MALAYSIAN DISASTER MANAGEMENT}

This research identified five main factors that contribute to ensure that all disaster victims during the disaster occurrence are well managed. The factors are information (van der Laan, van Dalen, Rohrmoser, \& Simpson, 2016; Yilmaz \& Kabak, 2016), communication (Madianou, Longboan, \& Ong, 2015; Martin, Nolte, \& Vitolo, 2016), collaboration (Martin et al., 2016; Richardson, Leeuw, \& Dullaert, 2016; Schniederjans, Ozpolat, \& Chen, 2016), coordination (Martin et al., 2016; Nagurney, Flores \& Soylu, 2016) and cooperation (Joshi \& Nishimura, 2016; Martin et al., 2016). These are the main success factors to manage humanitarian aid in disaster management.

However, there are always issues (refer Figure 2) that could interfere with the humanitarian aid distribution process between the disaster management team and the disaster victims. These issues could result in adverse consequences on the process as well as on the victims. Figure 2 shows the contributing factors to the issues in managing the humanitarian aid distribution process and their effects on the disaster victims. These issues must be overcome by the disaster management team in order to avoid problems in managing humanitarian aid distribution process. 


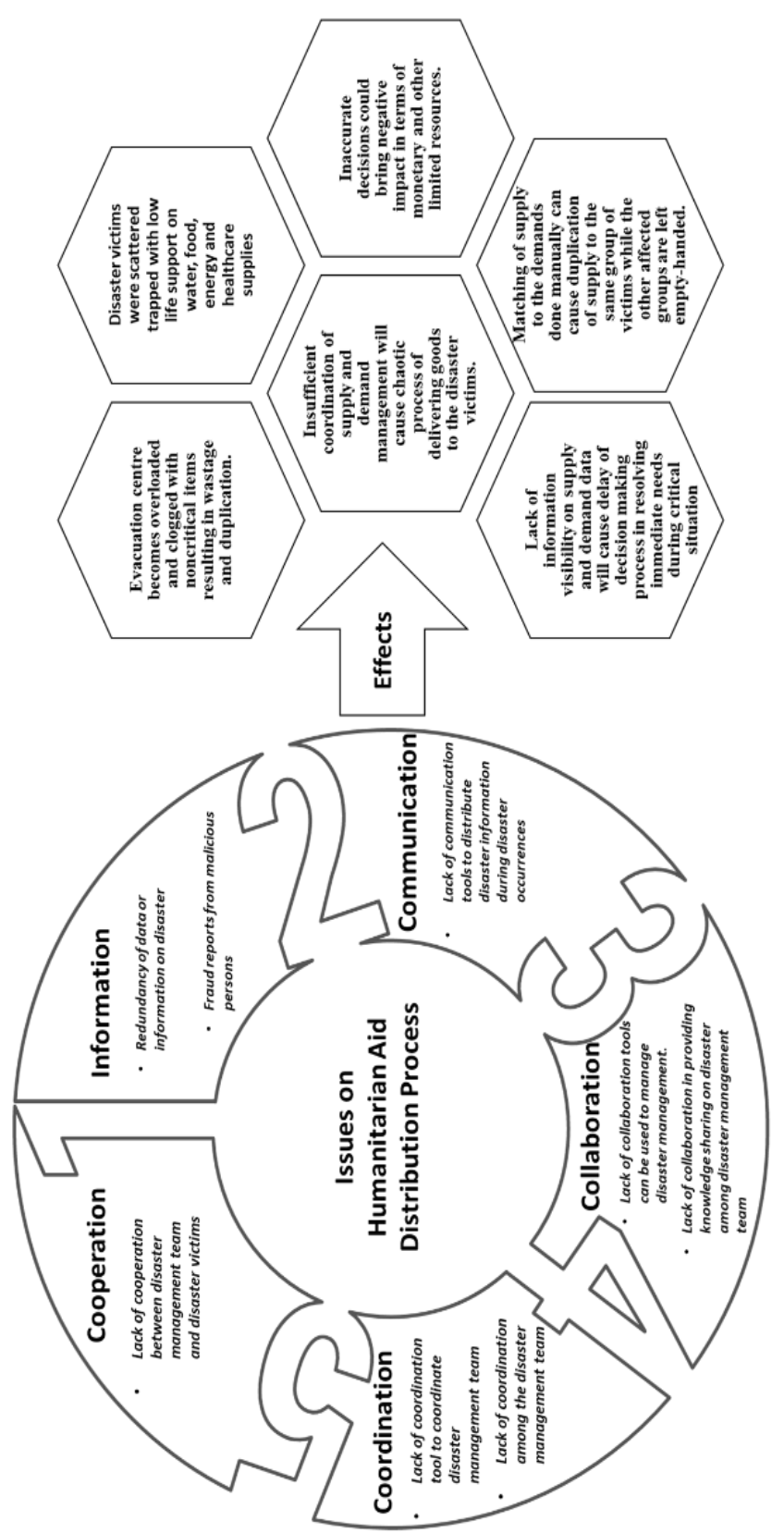

Figure 2: Issues within the Humanitarian Aid Distribution Process and their Effect on Disaster Victims

Source: Adapted from Baitenmann (1990); Gao, Barbier, Goolsby, \& Zeng (2011); Gao, Wang, Barbier, \& Liu (2011); Husain et al. (2014); Joshi \& Nishimura (2016); Martin et al. (2016); Mat Taib et al. (2014); Mohd Rodzi, Zakaria, \& Ahmad (2016); Nik Nazli, Sipon, \& Radzi (2014); White, Plotnick, Kushma, Hiltz, \& Turoff (2009); Yazid et al. (2014); Zakaria, Said, Ismail, \& Samsuddin (2014). 
PLANNING MALAYSIA

Journal of the Malaysia Institute of Planners (2018)

Based on the five main factors aforementioned, literature review reveals several issues in managing humanitarian aid distribution process during a disaster. The occurrence of the issues reflects the weaknesses in managing the aid distribution process within the disaster management team. The issues are summarised as follows:

1) Information

- Redundancy of information on the disaster-The information on the disaster could come from various sources or the same person and the same location in a short time. So, the disaster management team, especially the NGOs, might respond to an individual request at the same time (Gao, Barbier, et al., 2011). This is important in order to avoid redundancy of tangible products (Martin et al., 2016).

- Data on the disaster might be fraudulent reports from malicious persons Uncoordinated information could lead to fraudulent reports that could be retrieved by a malicious person for their own intentions (Gao, Barbier, et al., 2011; Ha, 2016).

2) Communication

- Lack of communication tools to distribute disaster information - Failures of communication channels, whether conventional phone lines, cell phone systems or radio channels, can severely harm the emergency response (Martin et al., 2016). Thus, this problem will lead to duplication of humanitarian aid between the NGOs (Baitenmann, 1990).

3) Collaboration

- Lack of collaboration tools that can be used to manage disaster management information - Most of the disaster management team, especially the NGOs, do not know how and where to share and retrieve the disaster information with or from others (White et al., 2009).

- Lack of collaboration in providing knowledge-sharing on a disaster within the disaster management team - The disaster management team have their own plan, SOP or activities in managing the humanitarian aid distribution process (Gao, Wang, et al., 2011; Nik Nazli et al., 2014).

4) Coordination

- Lack of coordination among the disaster management team - The current practices of disaster management are often unable to be harnessed effectively due to lack of coordination and efficient knowledge-sharing between the Government agencies and NGOs (Mohd Rodzi et al., 2016).

- Lack of coordination tools to manage real-time information on a disaster within the disaster management team - Real-time information is hard to deliver in a chaotic situation. There is a need for a tool that could coordinate disaster information despite the chaotic situation during a disaster occurrence (Gao, Wang, et al., 2011). 
Suzila Mohd, Mohamad Syazli Fathi, Aizul Nahar Harun, \& Noraini Omar Chong

Key Issues in The Management of the Humanitarian Aid Distribution Process During and Post-Disaster in Malaysia

\section{5) Cooperation}

- Lack of cooperation between the disaster management team and disaster victims - One of the challenging issues faced by Government agencies is to achieve cooperation with the disaster victims in terms of relocating them to the disaster-proof areas, especially in relocation phases (Joshi et al., 2016). Apart from that, the main reason to cooperate with NGOs is to avoid programme duplication, such as reconstruction of a permanent housing programme (Joshi \& Nishimura, 2016; Martin et al., 2016).

The issues discussed above have become major obstacles in managing humanitarian aid distribution process. These issues could not be ignored because they will lead to ineffectiveness and will disrupt the aid distribution process before, during and after a disaster in terms of the followings:

1. Evacuation centres become overloaded and clogged with noncritical items resulting in wastage and duplication (Husain et al., 2014);

2. A chaotic process of delivering goods to the disaster victims (Husain et al., 2014);

3. Delay in the decision-making process for resolving immediate needs during a critical situation (Husain et al., 2014);

4. Wastage and duplication of donated goods caused by improper inventory management (Husain et al., 2014);

5. Duplication of supply to the same group of disaster victims while other affected disaster victims are left empty-handed (Husain et al., 2014);

6. Disaster victims are scattered with low life-support on water, foods, energy, and healthcare supplies (Husain et al., 2014; Mat Taib et al., 2014; Yazid et al., 2014);

7. The negative impact in terms of monetary and other limited resources (Zakaria et al., 2014).

\section{DISCUSSION}

Improving the level of communication, coordination, collaboration and cooperation among the disaster management teams has been viewed as critical to optimise the flow of managing humanitarian aid distribution process during disaster. Yet, literature review shows that these are the weaknesses of the humanitarian aid distribution process in Malaysia. One of the factors that contributed to the issues is the absence of SOP in defining the roles and responsibilities of NGOs as supporting members in disaster management team. The SOP will have to comply with Directive No.20 and this is the gap that needs to be emphasized by NADMA as part of the disaster management policy. The SOP can be used by the Government agencies as a mechanism to coordinate the activities of NGOs during disaster. Previous studies have shown the importance 
PLANNING MALAYSIA

Journal of the Malaysia Institute of Planners (2018)

of a SOP as a guidance in planning and managing the NGOs during all phases of disaster management, with NADMA as the focal agency. This is important because the SOP is seen as a solution to the issues in humanitarian aid distribution process during a disaster.

\section{CONCLUSION AND RECOMMENDATIONS}

It is undeniable that humanitarian aid distribution process is an important activity in disaster management. The existence of the activity could lighten the burden of disaster victims by providing for their needs, shelters and emergency rescue. The establishment of a disaster management team in Malaysia shows that the Malaysian Government has striven to address disaster management issues. All roles and responsibilities of the Government agencies have been well defined in Directive No.20 but not those of the NGOs. There is a need to propose a SOP for the roles and responsibilities of NGOs as supporting members in managing humanitarian aid distribution process. Apart from that, there are issues occurring in managing the humanitarian aid distribution process that need to be avoided by the disaster management team. These issues could have significant effects on the humanitarian aid distribution process and on the disaster victims. However, the issues are seen as ones that can be resolved with the presence of a SOP. Therefore, further research will be needed to formulate a proposed SOP that will highlight the roles and responsibilities of NGOs as supporting members in humanitarian aid and developing systematic tools in order to address the issues in managing humanitarian aid distribution process.

\section{ACKNOWLEDGEMENT}

This work was financially supported by a Seed Grant from "Advanced Institute on Knowledge-Based Actions for Disaster Risk Reduction (AI-KBA)" of The International Council for Science - Regional Office for Asia and The Pacific (ICSU-ROAP).

\section{REFERENCES}

Abiew, F. K. (2012). Humanitarian action under fire: Reflections on the role of NGOs in conflict and post-conflict situations. International Peacekeeping, 19(2), 203216.

Asproth, V., \& Amcoff Nystrom, C. (2010, August). Preparing for Emergency Situations. In Ninth International Conference (CASYS '09), August 3-8, 2009, Liège, Belgium.

Baharin, S. S. K., Shibghatullah, A. S., \& Othman, Z. (2009, December). Disaster management in Malaysia: An application framework of integrated routing application for emergency response management system. In International Conference of Soft Computing and Pattern Recognition, December 4-7, 2009, Malacca, Malaysia. 
Suzila Mohd, Mohamad Syazli Fathi, Aizul Nahar Harun, \& Noraini Omar Chong

Key Issues in The Management of the Humanitarian Aid Distribution Process During and Post-Disaster in Malaysia

Baitenmann, H. (1990). NGOs and the Afghan war: The politicisation of humanitarian aid. Third World Quarterly, 12(1), 62-85.

Gao, H., Barbier, G., Goolsby, R., \& Zeng, D. (2011). Harnessing the crowdsourcing power of social media for disaster relief. IEEE Intelligent Systems, 26(3), 10-14.

Gao, H., Wang, X., Barbier, G., \& Liu, H. (2011). Promoting coordination for disaster relief - From crowdsourcing to coordination. In J. Salerno, S. J. Yang, D. Nau, \& S. K. Chai (Eds), Social Computing, Behavioral-Cultural Modeling and Prediction. SBP 2011. Lecture Notes in Computer Science, vol 6589 (pp. 197204). Springer, Berlin, Heidelberg.

Ha, K.-M. (2016). Disasters can happen to anybody: The case of Korea. Environmental Impact Assessment Review, 57, 1-9.

Husain, W., Abdul Rashid, N. A., Zainol, Z., Syed Mohamed, S. M., \& Ayub, M. A. (2014). Enhancing supply chain management system to support effective flood disaster relief operation. International Journal of Logistics Systems and Management, 5(6), 679-692.

Joshi, A., \& Nishimura, M. (2016). Impact of disaster relief policies on the cooperation of residents in a post-disaster housing relocation program: A case study of the 2004 Indian Ocean Tsunami. International Journal of Disaster Risk Reduction, 19, 258-264.

Madianou, M., Longboan, L., \& Ong, J. C. (2015). Finding a voice through humanitarian technologies? Communication technologies and participation in disaster recovery. International Journal of Communication, 9, 3020-3038.

Martin, E., Nolte, I., \& Vitolo, E. (2016). The four Cs of disaster partnering: Communication, cooperation, coordination and collaboration. Disasters, 40(4), 621-643.

Mastouri, T., Rekik, M., \& Fath, M. N. E. (2017). A mathematical approach to model humanitarian aid distribution in disaster area. International Journal of Emergency Management, 13(3), 252-267.

Mat Taib, S., Md Din, M. F., Nor Anuar, A., Yong, E. L., Hassan, N., \& Mohamed Rusli, N. (2014). Developing emergency evacuation kits in response to flood disaster by applying DPSIR framework. In Z. Yusop \& N. Mahpof (Eds.), Laporan akhir persidangan kajian bencana banjir 2014 (pp. 229-235).

Mohd Rodzi, Z. M., Zakaria, N. H., \& Ahmad, M. N. (2016). Ontology based knowledge integration framework for managing flood in Malaysia. Journal of Advanced Management Science, 4(6), 475-478.

Nagurney, A., Flores, E. A., \& Soylu, C. (2016). A Generalized Nash Equilibrium network model for post-disaster humanitarian relief. Transportation Research Part E: Logistics and Transportation Review, 95, 1-18.

National Security Council, N. (1997). Directive No.20. Malaysia: Majlis Keselamatan Negara.

Nik Nazli, N. N. N., Sipon, S., \& Radzi, H. M. (2014). Analysis of training needs in disaster preparedness. Procedia - Social and Behavioral Sciences, 140, 576-580.

Oloruntoba, R., \& Gray, R. (2006). Humanitarian aid: An agile supply chain? Supply Chain Management: An International Journal, 11(2), 115-120.

Omar Chong, N., \& Kamarudin, K. H. (2017, September). Issues and challenges in disaster risk management in Malaysia: From the perspective of agencies. In 
Persidangan Geografi dan Alam Sekitar kali ke-6, September 26-27, 2017, Tanjung Malim, Malaysia.

Richardson, D. A., Leeuw, S., \& Dullaert, W. (2016). Factors affecting global inventory prepositioning locations in humanitarian operations - A Delphi study. Journal of Business Logistics, 37(1), 59-74.

Schniederjans, D. G., Ozpolat, K., \& Chen, Y. (2016). Humanitarian supply chain use of cloud computing. Supply Chain Management: An International Journal, 21(5), 569-588.

Tan, C. T., Raswahan, A. B., Koh, F. P., Lim, C. S., \& Ismail, R. (2013) Memperkukuhkan ketahanan nasional melalui pengurusan risiko bencana di Malaysia: Peranan pihak berkuasa tempatan, hospital dan sekolah. Bangi, Institute Alam Sekitar dan Pembangunan (LESTARI), Universiti Kebangsaan Malaysia.

Thérien, J.-P., \& Lloyd, C. (2000). Development assistance on the brink. Third World Quarterly, 21(1), 21-38.

van der Laan, E., van Dalen, J., Rohrmoser, M., \& Simpson, R. (2016). Demand forecasting and order planning for humanitarian logistics: An empirical assessment. Journal of Operations Management, 45, 114-122.

White, C., Plotnick, L., Kushma, J., Hiltz, S. R., \& Turoff, M. (2009). An online social network for emergency management. International Journal of Emergency Management, 6(3-4), 369-382.

Yazid, A. S., Hussin, M. R., Wan Daud, W. N., Abdullah, A. A., \& Salleh, F. (2014). Developing a national disaster risk reduction framework (DRR) for flood risk management. In Z. Yusop \& N. Mahpof (Eds.), Laporan akhir persidangan kajian bencana banjir 2014 (pp. 193-202).

Yilmaz, H., \& Kabak, Ö. (2016). A multiple objective mathematical program to determine locations of disaster response distribution centers. IFACPapersOnLine, 49(12), 520-525.

Zakaria, N. B., Said, J., Ismail, I. S., \& Samsuddin, M. E. (2014). Knowledge base framework to support decision making for flood disaster relief. In Z. Yusop \& N. Mahpof (Eds.), Laporan akhir persidangan kajian bencana banjir 2014 (pp. 115-118). 